\title{
Impact of Intangibles on Corporate Value
}

\author{
Kazunori Ito ${ }^{1}$, Shu Umeda ${ }^{2}$, Hiroyuki Sekiya ${ }^{3}$ \\ ${ }^{1}$ Senshu University, Tokyo, Japan \\ ${ }^{2}$ Kanazawa-Seiryo University, Kanazawa, Japan \\ ${ }^{3}$ Hokkai-Gakuen University, Sapporo, Japan \\ Email: itoh@isc.senshu-u.ac.jp, shu199umeda@gmail.com, sekiya@hgu.jp
}

How to cite this paper: Ito, K., Umeda, S., \& Sekiya, H. (2020). Impact of Intangibles on Corporate Value. Journal of Human Resource and Sustainability Studies, 8, 131-150. https://doi.org/10.4236/jhrss.2020.82008

Received: May 16, 2020

Accepted: June 6, 2020

Published: June 9, 2020

Copyright $\odot 2020$ by author(s) and Scientific Research Publishing Inc. This work is licensed under the Creative Commons Attribution International License (CC BY 4.0).

http://creativecommons.org/licenses/by/4.0/

(c) (i) Open Access

\begin{abstract}
Numerous intangibles can affect corporate value; for example, human assets, organizational assets, information assets, and corporate reputation. As discussions about intangibles have intensified, the number of empirical studies focused on the relationship between intangibles and corporate value has increased. Previous studies have demonstrated the relationship between intangibles and corporate value as individual or combined elements; however, no previous empirical study has incorporated strategies into the analysis of the relationship between intangibles and corporate value. The present study analyzes how different strategies and management control systems impact intangibles, the source of corporate value. Three discoveries were made. The first reveals that intangibles consist of corporate reputation, innovation, information assets, and organizational assets, but not human assets, which turn out to be linked to innovation. This result indicates that the skills and creativity of employees play a major role in innovation. The second discovery shows that corporate value consists of economic value, social value, and organizational value. This result agrees with the view of others who have asserted that all stakeholders are in an equal relationship. Therefore, it can be said that companies take various stakeholders into consideration when creating value. The third discovery shows that when different strategies and management control systems are adopted, different intangibles affect corporate values. For instance, in prospector companies, reputation does not impact corporate value; these firms aim to create new markets through innovation, and are less concerned with reducing reputational risk. By contrast, in defender companies, innovation does not affect corporate value; these firms place emphasis on preserving their reputation to retain existing markets and customers.
\end{abstract}

\section{Keywords}

Intangibles, Corporate Value, Corporate Strategy, Management Control Systems 


\section{Introduction}

As the economic environment shifted from an industry-led society to a knowledge-led society, intangibles, as a contributor to corporate value, became increasingly more important. In response to the growing interest in intangibles, research on intangibles became more common. The studies on intangibles emerged in the 1980s, and the number of studies jumped in the 1990s (Umeda, 2018: p. 35). However, the term "intangibles" has various components, such as human assets, organizational assets, information assets, and corporate reputation.

Previous studies have examined the relationship between intangibles and corporate value as individual or combined elements. However, when different strategies are adopted, the intangibles that contribute to creating corporate value also change (Kaplan \& Norton, 2004: p. 24). This finding prompted Ito \& Sekiya (2016) to propose a new framework that incorporated strategies and management control systems into the relationship model between intangibles and corporate value; no previous empirical study had incorporated strategies into this relationship. The present study elucidates how differences in strategy and management control systems impact intangibles, the source of corporate value.

The remainder of this paper is organized as follows: Section 2 clarifies the definition of intangibles and outlines the strategy theory by Miles \& Snow (1978), the management control system by Simons (1987), and the concept of organizational ambidexterity proposed by O'Reilly \& Tushman (2004). In Section 3, we review previous empirical studies on the relationship between intangibles and corporate value. In Section 4, we present the analysis framework and hypotheses of this study. We verify those hypotheses in Section 5 and discuss their results in Section 6. Lastly, we detail the contribution of this study and future research opportunities.

\section{Intangibles, Strategies, and Management Control Systems}

In this section, we summarize how research on intangibles has evolved over the years. Because intangibles are closely related to strategies, we also review the study conducted by Miles \& Snow (1978), who proposed four categories of strategies, and the management control system proposed by Simons. Finally, we will outline the concept of organizational ambidexterity, which has been gaining attention in recent years.

\subsection{Intangibles}

In financial accounting research, purchased goodwill is the only intangible asset that has conventionally been recognized as an asset. However, other intangibles quickly gained importance from the late 1990s. The price-to-book ratio (PBR) of companies listed in the Standard \& Poor's 500 stock index increased from one in 1980 to seven in 2000. In other words, investors began to realize that companies had sources of excess profits that are not reflected on their balance sheets. 
Meanwhile, management accounting research focused on how to manage intangibles. Kaplan \& Norton (2004) proposed the concept of the balanced scorecard (BSC), an intangibles management system. With BSC, they proposed that intangibles should be measured and managed by readiness assessments as the ultimate source of corporate value creation.

\subsection{Strategy and Management Control Systems}

Several researchers have given their interpretations of the definition of strategy. Authors such as Ansoff (1965), Andrews (1987), and Porter (1980) share the stance of developing plans strategically, according to the given strategy. This line of thinking is called content strategy approach, which sees strategies and environments as static elements. With the content strategy approach, organizations can adapt themselves to the strategy and environment and thereby indicate a clear direction, enhance commitment, strengthen departmental coordination, and have a long-term perspective.

In contrast, Miles \& Snow (1978), Mintzberg, Ahlstrand, \& Lampel (1998) and Burgelman (2002) see the environment as a dynamic element that is constantly changing and one that the company itself can influence. This is called strategy process approach, which does not emphasize official control as much as the content strategy approach does (Chenhall, 2005). Instead, it focuses on creating a competitive advantage by listening to novel ideas and adapting to the constantly changing environment.

Strategies can only be realized when linked to management control systems. Using the strategy types ${ }^{1}$ conceived by Miles \& Snow (1978), Simons $(1987,1990)$ analyzed whether there were differences in the management control of prospector and defender companies based on interviews and questionnaire surveys. The analysis confirmed the existence of such differences; in prospectors, the strategy and budget are frequently discussed in the company, and financial targets are determined in a bottom-up approach. Meanwhile, in defender companies, the developed strategies are seldom discussed, the budget is not revised, and the companies' financial targets are conveyed in a top-down manner.

Ambidextrous organizations, which seek to excel as both prospectors and defenders, have been in the spotlight in recent years. O’Reilly \& Tushman (2004: p. 74) stated that companies must be able to improve their existing products and business processes while also innovating for the future, which they called organizational ambidexterity. The main characteristic of ambidextrous organizations is that they aim to expand their existing businesses and develop new businesses at the same time; that is, they act as both defenders and prospectors simultaneously.

${ }^{1}$ Miles \& Snow (1978) analyzed relatively stable product market areas and proposed four types of strategies: defenders, which focus on making existing activities more efficient; prospectors, which focus on innovation and continuously search for product and market opportunities; analyzers, which have attributes of both defenders and prospectors; and reactors, which lack responsiveness to environmental changes. Simons $(1987,1990)$, however, did not consider analyzers and reactors. 


\section{Empirical Research on Intangibles and Corporate Value}

There are many examples of empirical studies that explore the relationship between corporate value and various intangibles such as human assets, organizational assets, information assets, corporate reputation, and innovation (see Table 1). These studies are broadly divided into those focused on specific intangibles, and those that see intangibles as a combination of various elements. In this section, we outline these previous studies according to this classification.

\subsection{Studies Focused on Specific Intangibles}

Empirical research on intangibles has explored various areas such as human assets, organizational assets, information assets, corporate reputation, innovation, customer assets, brand equity, and relational assets.

Table 1. Previous studies.

\begin{tabular}{|c|c|c|c|c|c|c|c|c|}
\hline \multirow[b]{2}{*}{ Study authors } & \multicolumn{8}{|c|}{ Intangibles analyzed } \\
\hline & $\begin{array}{c}\text { Human } \\
\text { assets }\end{array}$ & $\begin{array}{l}\text { Organizational } \\
\text { assets }\end{array}$ & $\begin{array}{c}\text { Information } \\
\text { assets }\end{array}$ & Reputation & Innovation & $\begin{array}{l}\text { Customer } \\
\text { assets }\end{array}$ & Brand & $\begin{array}{c}\text { Relational } \\
\text { assets }\end{array}$ \\
\hline Fombrun \& Shanley (1990) & & & & $\mathrm{O}$ & & & & \\
\hline Riahi-Belkaoui \& Pavlik (1991) & & & & $\mathrm{O}$ & & & & \\
\hline Subramanian \& Nilakanta (1996) & & & & & O & & & \\
\hline Kowalczyk \& Pawlish (2002) & & $\mathrm{O}$ & & $\mathrm{O}$ & & & & \\
\hline Roberts \& Dowling (2002) & & & & $\mathrm{O}$ & & & & \\
\hline Carmeli (2004) & $\mathrm{O}$ & & & $\mathrm{O}$ & & & & \\
\hline Youndt, Subramaniam, \& Snell (2004) & $\mathrm{O}$ & $\mathrm{O}$ & & & & & & $\mathrm{O}$ \\
\hline Carmeli \& Tishler (2005) & $\mathrm{O}$ & $\mathrm{O}$ & & $\mathrm{O}$ & & & & \\
\hline Tseng \& Goo (2005) & $\mathrm{O}$ & $\mathrm{O}$ & & & $\mathrm{O}$ & & & $\mathrm{O}$ \\
\hline Hosomi $(2009,2011,2014)$ & O & $\mathrm{O}$ & $\mathrm{O}$ & $\mathrm{O}$ & $\mathrm{O}$ & & & $\mathrm{O}$ \\
\hline Yee, Yeung, \& Cheng (2010). & $\mathrm{O}$ & & & & & $\mathrm{O}$ & & \\
\hline Ito, Ito, Shinmura, \& Sakurai (2011) & & & & $\mathrm{O}$ & & & & \\
\hline Chien \& Chao (2011) & $\mathrm{O}$ & $\mathrm{O}$ & $\mathrm{O}$ & & & & & \\
\hline Mithas, Ramasubbu, \& Sambamurthy (2011) & & $\mathrm{O}$ & $\mathrm{O}$ & & & $\mathrm{O}$ & & \\
\hline Ponzi, Fombrun, \& Gardberg (2011) & & & & $\mathrm{O}$ & & & & \\
\hline Iwata (2012) & & & & $\mathrm{O}$ & & & & \\
\hline Nihon Kanrikaikei Gakkai Study Group (2015) & $\mathrm{O}$ & $\mathrm{O}$ & $\mathrm{O}$ & $\mathrm{O}$ & $\mathrm{O}$ & $\mathrm{O}$ & $\mathrm{O}$ & \\
\hline Donate, Peña, \& Sánchez de Pablo (2016) & $\mathrm{O}$ & $\mathrm{O}$ & & & $\mathrm{O}$ & & & \\
\hline Ito \& Sekiya (2016) & & $\mathrm{O}$ & $\mathrm{O}$ & $\mathrm{O}$ & O & & & \\
\hline França \& Rua (2018) & $\mathrm{O}$ & $\mathrm{O}$ & $\mathrm{O}$ & & & & & $\mathrm{O}$ \\
\hline Shubita (2019) & $\mathrm{O}$ & $\mathrm{O}$ & & & & & & \\
\hline Ubaldo \& Siedschlag (2020) & & $\mathrm{O}$ & $\mathrm{O}$ & & $\mathrm{O}$ & & & \\
\hline
\end{tabular}


Youndt, Subramaniam, \& Snell (2004) conducted a study that elucidated the relationship between human assets, organizational assets, and corporate value. According to their research, companies that have human assets and organizational assets have higher corporate value than those that do not. Also, Carmeli (2004) added corporate reputation to human assets and organizational assets and analyzed their relationship with corporate value. Their analysis revealed that human assets and organizational assets influence corporate value through corporate reputation.

Mithas, Ramasubbu, \& Sambamurthy (2011) conducted a study that looked at information assets. They focused on information management ability and demonstrated that information assets influence customer and organizational assets, resulting in an increase in corporate value. There are also many studies that focus on corporate reputation. For example, Riahi-Belkaoui \& Pavlik (1991) indicated that when corporate value increases, so does corporate reputation. Relatedly, Roberts \& Dowling (1997) demonstrated that there is also an opposite causal relationship in which corporate reputation affects corporate value. In later research, Roberts \& Dowling (2002) demonstrated that there is a permanent relationship in which the corporate value of the previous term increases the corporate reputation of the current term and further affects the corporate value of the following term.

\subsection{Intangibles as a Combination of Elements}

Intangibles cannot create value individually. Maximum value is produced when all intangibles in the company are integrated (Kaplan \& Norton, 2004: pp. 259-260). Hence, some studies perceive intangibles as a combination of multiple elements (Tseng \& Goo, 2005; Nihon Kanrikaikei Gakkai Study Group, 2015; Hosomi, 2009, 2011, 2014; Ito \& Sekiya, 2016; França \& Rua, 2018; Shubita, 2019; Ubaldo \& Siedschlag, 2020). Nihon Kanrikaikei Gakkai Study Group (2015) and Hosomi $(2009,2011)$ revealed that each intangible affects the others, and all intangibles affect corporate value.

Meanwhile, Ito, \& Sekiya (2016) showed that organizational assets have an impact on information assets, information assets on product innovation, product innovation on logistics innovation, logistics innovation on corporate reputation, and corporate reputation on corporate value. In their view, organizational assets are the ultimate source of corporate value. Their study is characterized by a broad definition of corporate value, extending it beyond economic value to include customer value, social value, and organizational value. Moreover, Hosomi (2014) used multiple intangibles as one variable to demonstrate how they directly affect corporate value.

Intangibles only create value when linked to a strategy. Further, the intangibles regarded as important by a company vary according to the strategies the company adopts (Kaplan \& Norton, 2004: p. 24). Until recently, there were no examples of complex empirical studies on intangibles that incorporated strategies and management control systems into the models. Therefore, Ito \& Sekiya (2016) proposed a theoretical framework that incorporates strategies (see Figure 1). 


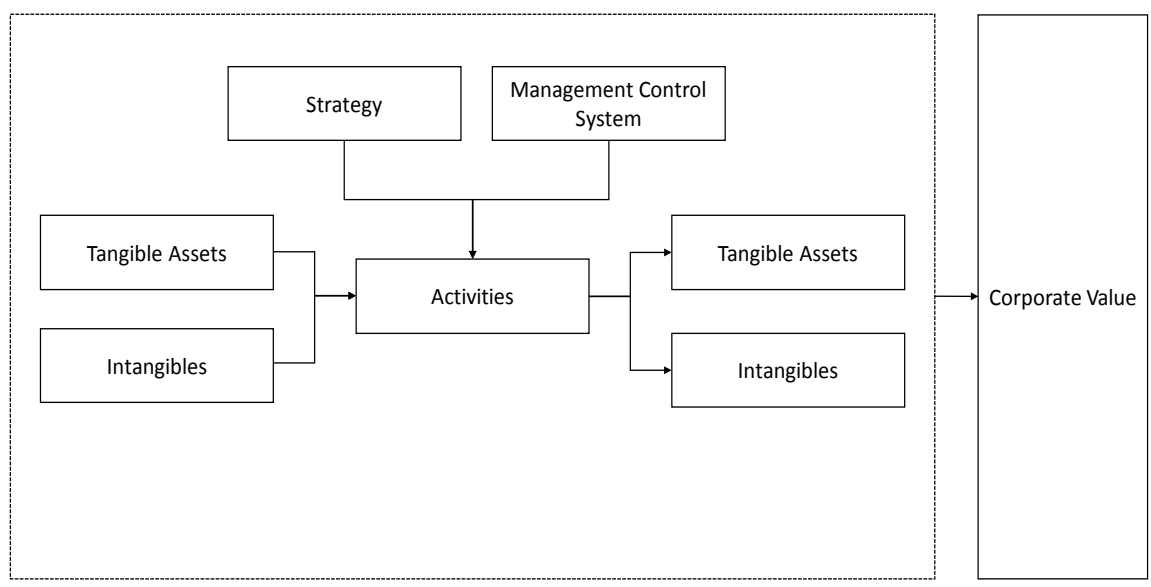

Figure 1. Theoretical framework proposed by Ito \& Sekiya (2016: p. 23).

According to the framework of Figure 1, companies use tangible assets and intangibles at the beginning of the term to carry out activities based on their strategy and management control, which results in tangible assets and intangibles created at the end of the term. Ultimately, the difference between the beginning and the end of the term adds to, or subtracts from, corporate value. Ito \& Sekiya (2016) cite the prospector and defender strategies proposed by Miles \& Snow (1978) and point out that these strategies focus on different types of activities. They also mention the importance of having a management control system that fits the strategy. The main characteristic of this study is that it incorporated strategies and management control systems into the relationship between intangibles and corporate value.

\section{Hypothesis Setting}

In this section, we propose the hypotheses of this study. We first identify the components of intangibles and corporate value, then discuss the impact of intangibles on corporate value, and finally propose the model used in the analysis.

\subsection{Components of Intangibles and Corporate Value}

Intangibles have been studied from various aspects, such as knowledge (Nonaka \& Takeuchi, 1996), human assets (Becker, 1964; Uchiyama, 2010), research and development (Nishimura, 2001), information assets (Sakurai, 1987; Kozakai, 2008), organizational culture (Peters \& Waterman, 1982; Ito, 2007), and corporate reputation (Fombrun \& Shanley, 1990; Riahi-Belkaoui \& Pavlik, 1991).

Later, studies emerged that viewed intangibles with a broader perspective and sought to identify their components. Edvinsson \& Malone (1997) called intangibles intellectual capital and defined them as a component of market value. According to their classification, intellectual capital consists of human capital and structural capital. Structural capital, in turn, consists of customer capital and organizational capital, and organizational capital of innovation capital and process capital. This study is characterized by the fact that it breaks down intellectual capital into components. 
Also, Lev (2001), who considered environmental changes such as globalization and advancement of information technology, only recognized intangibles that are important for innovation. At the same time, he classified intangibles into innovation, human assets, and organizational assets.

Kaplan \& Norton, who proposed expressing the causal relationship between intangibles and corporate value for the development and execution of strategies, defined intangibles as the "ultimate source of sustainable value creation" (Kaplan \& Norton, 2004: p. 7). They also suggested that human capital, information capital, and organizational capital support value creation from the perspective of learning and growth.

Unlike these three works, Blair \& Wallman (2001) conducted a study that classified intangibles from the perspective of measurability. According to the measurability of intangibles, intellectual property, an asset that appears on a firm's balance sheet, is on the first level. On the second level are assets such as brand and corporate reputation, which are controllable but cannot be sold separately from the company. Intangibles such as human assets, organizational assets, and information assets, over which the company has no control whatsoever and are not recognized as assets in accounting, are on the third level.

Based on these previous studies, we define corporate reputation, innovation, human assets, organizational assets, and information assets as the components of intangibles. Considering that product brand, customer assets, and relational assets are deeply connected to the company's reputation with stakeholders, we placed them within corporate reputation, and thus set Hypothesis 1:

$\mathrm{H} 1$ : Intangibles consist of corporate reputation, innovation, human assets, organizational assets, and information assets.

Generally speaking, the objective of companies is to create corporate value, the definition of which changes depending on the stakeholder. For example, the economic value that focuses on shareholders and banks, as is the case of McKinsey \& Company Inc. (2010), consists of financial performance indicators such as return on assets (ROA) and return on equity (ROE). Customer value, which places customers at the top, as proposed by Drucker (1954), aims to increase customer satisfaction and earn their trust. Social value sees social contribution through corporate activities and the reduction of the environmental load as a corporate value. If the organization turns its eyes to its employees, it aims at increasing employee-focused organizational value that fosters organizational culture, equal opportunities, and fair evaluation by sharing the same management philosophy, in line with the humanism proposed by Itami (1987).

Some believe that instead of increasing a single corporate value, companies should seek improvement across multiple values at the same time. One such example is corporate social responsibility (CSR), which aims at increasing shareholder value, social value, and environmental value. With CSR, social value and environmental value have been emphasized as antitheses of shareholder value, but in recent years, a corporate value known as creating shared value (CSV) has 
gained attention (Porter \& Kramer, 2011). CSV sees the subset where social value and economic value overlap as a corporate value. While CSV does not ignore customers and employees, it does not contain customer value and organizational value directly.

Finally, there is the concept of stakeholder value, which sees all values that concern all stakeholders-shareholder value, customer value, social value, and organizational value - as total corporate value (Sakurai, 2015: p. 40).

Based on the significant environmental changes of modern times, Freeman, Harrison, \& Wicks (2007) have consistently claimed that rather than shareholders sitting at the top of the stakeholder pyramid, all stakeholders are in an equal relationship. Therefore, to create value in a continuous fashion, companies must consider the value of all stakeholders in their management. The factor analysis of corporate value carried out by Ito \& Sekiya (2016) revealed that corporate value consists of economic value, customer value, social value, and organizational value. A survey conducted by Aoki, Iwata, \& Sakurai (2009) also showed that many managers in Japan see corporate value as economic value, social value, and organizational value.

Based on the above, in this study, we see corporate value as stakeholder value, in line with the view of Freeman, Harrison, \& Wicks (2007), and set Hypothesis 2:

H2: Corporate value consists of economic value, customer value, social value, and organizational value.

For corporate reputation, we used the seven evaluation items of RepTrak ${ }^{\mathrm{TM}}$, a platform developed by the Reputation Institute (Ponzi, Fombrun, \& Gardberg, 2011). Innovation is typically divided into product innovation and process innovation (Odagiri, 2010: p. 190), but here, we consider product innovation as a process innovation that measures the elements that overlap with the seven evaluation items of RepTrak ${ }^{\mathrm{TM}}$ and innovation in the entire value chain. Also, the question items concerning human assets and organizational assets were created based on Kaplan \& Norton (2004), and those concerning information assets on Mithas, Ramasubbu, \& Sambamurthy (2011).

As mentioned before, maximum value is created when all intangibles in the company are integrated, making the link between each intangible important. Ito \& Sekiya (2016) proposed a model where organizational assets have an impact on information assets, information assets on human assets, human assets on innovation, and innovation on corporate reputation. Therefore, in this study, we used this model to set the following Hypothesis 3:

H3: Organizational assets have an impact on information assets, information assets on human assets, human assets on innovation, and innovation on corporate reputation.

\subsection{Impact of Intangibles on Corporate Value}

According to Simons (1987), prospector companies tend to actively use interactive control systems. In other words, in the process of prospecting for market opportunities, prospector companies promote organizational learning through 
dialogue and discussion to create new strategies and tactics (Nishii, 2012: p. 174). By contrast, defender companies tend to use diagnostic control systems, meaning that their target is determined in a top-down manner, with no mid-term changes in the strategy or budget, and these are evaluated based on the planned values.

In short, the prospecting strategy has more affinity with interactive control and the defender strategy with diagnostic control. When developing these two strategies simultaneously-that is, when applying organizational ambidexterity-both interactive control and diagnostic control must function together successfully.

The prospecting strategy company prospects for market opportunities and actively seeks to create innovations. Therefore, innovation is likely to be a more important intangible than in the company following a defender strategy. The defender strategy company seeks to protect the existing market by maintaining or building the company's reputation with its existing customers; as such, corporate reputation may be a more important intangible than under the prospecting strategy. In the case of ambidextrous organizations, which have both prospector and defender characteristics, it is believed that all intangibles affect their corporate value.

The analysis above suggests that when different strategies and management control systems are adopted, corporate value is affected by different intangibles. Thus, Hypothesis 4 and Hypothesis 5 are set:

H4: Intangibles impact corporate value.

H5: In prospector companies that emphasize interactive control, defender companies that emphasize diagnostic control, and companies that emphasize organizational ambidexterity, the intangibles that impact corporate value are different.

\subsection{Analysis Model}

Figure 2 illustrates the relationship between intangibles and corporate value represented in terms of the hypotheses above. This model indicates that intangibles consist of corporate reputation, innovation, human assets, information assets,

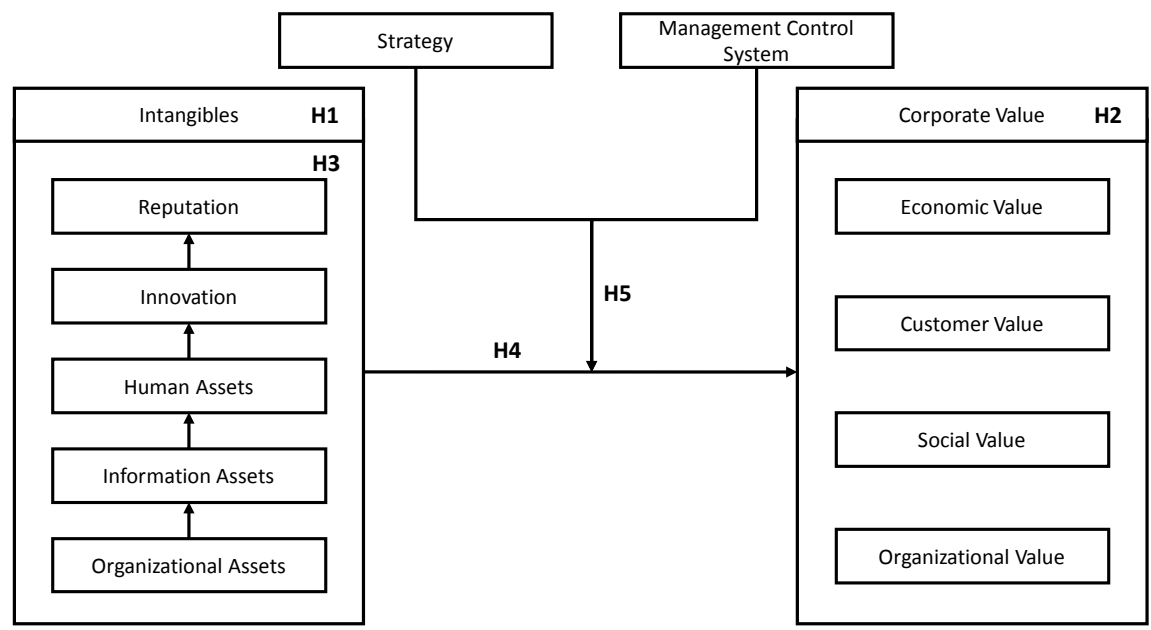

Figure 2. Analysis model. 
and organizational assets, and corporate value consists of economic value, customer value, social value, and organizational value. The model assumed that each intangible has a causal relationship with the other intangibles, and strategies and management control systems influence the relationship between intangibles and corporate value.

\section{Hypothesis Verification}

In this section, we verify the hypotheses proposed above. The first step is the description of the survey outline, followed by the verification of the hypotheses in the following order: the components of intangibles of Hypothesis 1, the components of corporate value of Hypothesis 2, the causal relationship between intangibles of Hypothesis 3, the impact of intangibles on corporate value of Hypothesis 4 , and the impact of strategies and management control systems on the relationship between intangibles and corporate value of Hypothesis 5. For the analysis, SPSS Statistics23 and Amos25 of IBM SPSS were used.

\subsection{Survey Outline}

Based on the database called D-Vision, owned by Diamond, Inc., we mailed a questionnaire survey to 1386 companies listed on the First Section of the Tokyo Stock Exchange. The questionnaire was sent to a corporate planning executive or manager of each company. It was sent on January 20, 2017, with the response deadline set to February 28. Ultimately, 163 companies replied (response rate: $11.8 \%$ ), of which 149 responses were valid (response rate: 10.75\%). A chi-square goodness-of-fit test between the sample and responding firms indicated no significant difference in industry distributions $\left(\chi^{2}=44.365, d f=38, p=0.221\right)$. The response choices to each question were presented on a 7 -point Likert scale. We checked for ceiling and floor effect on the question items; ceiling effect was observed on questions about corporate value (II 6, II 7, II 11, and II 12), which were then excluded from the analysis. We measured the Intangibles components using 29 questions (see Table 2, I06 - I34) and measured the Corporate Value components using 21 questions (see Table 3, II01 - II21).

\subsection{Confirmatory Factor Analysis of Intangibles and Corporate Value}

A confirmatory factor analysis was carried out based on $\mathrm{H} 1$, for 34 intangible items. Table 4 shows the analysis results. Because it consists of items related to data and information, as well as hardware and software, the first factor was labeled "information assets". The second factor, which expresses innovations, such as the employees' advanced skills and job proficiency level, as well as the construction of management processes of research and development, was labeled "innovation". The third factor, which corresponds to the seven evaluation items of $\operatorname{RepTrak}^{\mathrm{TM}}$ related to reputation, was labeled "corporate reputation". The fourth factor, which indicates the creation of vision and mission, as well as organizational transparency, was labeled “organizational assets”. 
Table 2. Questionnaire items and descriptive statics of intangibles.

\begin{tabular}{|c|c|c|c|c|c|}
\hline Question items & Size & Mini & Max & Mean & $\begin{array}{l}\text { Standard } \\
\text { deviation }\end{array}$ \\
\hline I06_Product and service function reputation & 149 & 1 & 7 & 5.48 & 0.96 \\
\hline I07_Innovative reputation & 149 & 1 & 7 & 4.41 & 1.12 \\
\hline I08_Financial performance reputation & 149 & 2 & 7 & 5.23 & 1.17 \\
\hline I09_Leadership reputation & 149 & 3 & 7 & 4.91 & 0.99 \\
\hline I10_Governance reputation & 149 & 2 & 7 & 4.97 & 0.98 \\
\hline I11_Innovative reputation & 149 & 1 & 7 & 4.65 & 0.97 \\
\hline I12_Work environment reputation & 149 & 2 & 7 & 4.60 & 0.95 \\
\hline I13_Construction of R\&D management process & 149 & 1 & 7 & 4.38 & 1.22 \\
\hline $\begin{array}{l}\text { I14_Construction of manufacturing/sales management } \\
\text { process }\end{array}$ & 149 & 1 & 7 & 4.70 & 1.04 \\
\hline I15_Construction of delivery management process & 149 & 1 & 7 & 4.40 & 1.05 \\
\hline $\begin{array}{l}\text { I16_Devropment of management process for the entire } \\
\text { business process }\end{array}$ & 149 & 1 & 7 & 4.60 & 0.98 \\
\hline I17_Devropmet of management process of support work & 149 & 1 & 6 & 4.36 & 0.93 \\
\hline I18_R\&D capabilities of employees & 149 & 1 & 6 & 4.43 & 1.13 \\
\hline I19_Advanced skills of employees & 149 & 1 & 7 & 4.74 & 1.03 \\
\hline I20_Employee creativity & 149 & 1 & 6 & 4.24 & 1.06 \\
\hline I21_Skill level of employees & 149 & 1 & 7 & 5.11 & 0.93 \\
\hline I22_Knowledge development for employees & 149 & 1 & 7 & 4.73 & 0.99 \\
\hline I23_Availability of data and information & 149 & 1 & 6 & 4.63 & 1.11 \\
\hline $\begin{array}{l}\text { I24_Integrity, reliability, accuracy, timeliness, safety, and } \\
\text { credibility of data and information }\end{array}$ & 149 & 1 & 7 & 4.81 & 1.12 \\
\hline I25_Relationship of data and information with strategy & 149 & 1 & 6 & 4.48 & 1.01 \\
\hline I26_User-friendliness of hardware and software & 149 & 1 & 6 & 4.29 & 1.00 \\
\hline I27_Relationship of hardware and software with strategy & 149 & 1 & 7 & 4.24 & 1.03 \\
\hline I28_leadership & 149 & 3 & 7 & 5.10 & 0.91 \\
\hline I29_Management system & 149 & 3 & 7 & 5.05 & 0.94 \\
\hline $\begin{array}{l}\text { I30_Corporate philosophy (mission) setting and } \\
\text { organizational penetration }\end{array}$ & 149 & 2 & 7 & 5.30 & 0.94 \\
\hline I31_Vision setting and organizational penetration & 149 & 2 & 7 & 5.10 & 0.96 \\
\hline I32_Fair reward system & 149 & 2 & 6 & 4.91 & 0.94 \\
\hline I33_Linking strategies with employee goals & 149 & 1 & 6 & 4.84 & 1.08 \\
\hline I34_Collaboration between organizations & 149 & 1 & 6 & 4.51 & 1.13 \\
\hline
\end{tabular}

Table 3. Questionnaire items and descriptive statics of corporate value.

\begin{tabular}{lccccc}
\hline \multicolumn{1}{c}{ Question items } & Size & Mini & Max & Mean & $\begin{array}{c}\text { Standard } \\
\text { deIliation }\end{array}$ \\
\hline $\begin{array}{l}\text { II01_Increasing return on inIIestment (ROI) and } \\
\text { return on sales }\end{array}$ & 149 & 2 & 7 & 5.70 & 1.06 \\
\hline
\end{tabular}




\section{Continued}

\begin{tabular}{llllll}
\hline II02_Increasing ordinary income and net income & 149 & 3 & 7 & 5.96 & 0.91 \\
II03_Increasing return on equity (ROE) & 149 & 1 & 7 & 5.37 & 1.25 \\
II04_Increasing future cash flow & 149 & 3 & 7 & 5.40 & 0.99 \\
II05_Increasing market capitalization & 149 & 1 & 7 & 5.33 & 1.04 \\
II06_ImproIIement of customer (business partner) & 149 & 4 & 7 & 6.23 & 0.77 \\
reliability & & & & & \\
II07_ImproIIment of customer (business partner) & 149 & 3 & 7 & 6.24 & 0.79 \\
satisfaction & 149 & 1 & 7 & 5.40 & 1.48 \\
II08_ImproIIement of customer satisfaction & 149 & 3 & 7 & 5.47 & 1.02 \\
II09_ImproIIement of trust from suppliers & 149 & 1 & 7 & 5.35 & 1.14 \\
II10_Relationship with local residents & 149 & 4 & 7 & 6.24 & 0.75 \\
II11_Employee compliance & 149 & 3 & 7 & 6.19 & 0.86 \\
II12_Business ethics & 149 & 4 & 7 & 6.07 & 0.88 \\
II13_Business fairness & 149 & 4 & 7 & 6.05 & 0.86 \\
II14_Corporate goIIernance & 149 & 2 & 7 & 5.51 & 1.04 \\
II15_Reduction of enIIironmental load & 149 & 2 & 7 & 5.57 & 1.03 \\
II16_ImproIIement of employee satisfaction & 149 & 2 & 7 & 5.60 & 1.11 \\
II17_ImproIIement of employee motiIIation & 149 & 3 & 7 & 5.58 & 1.02 \\
II18_Fair treatment of employees & 2 & 7 & 5.54 & 1.10 \\
II19_Leadership deIIelopment & 149 & 7 & 5.54 & 1.01 \\
II20_Sense of togetherness in the organization & 149 & 5.54 & 1.08 \\
II21_Sharing organizational culture & 149 & & & & \\
\hline
\end{tabular}

Table 4. Factor analysis of intangibles.

\begin{tabular}{|c|c|c|c|c|c|c|c|c|c|}
\hline Question items & Size & Mini & Max & Mean & $\begin{array}{l}\text { Standard } \\
\text { deviation }\end{array}$ & $\begin{array}{l}\text { Information } \\
\text { assets }\end{array}$ & Innovation & Reputation & $\begin{array}{l}\text { Organizational } \\
\text { assets }\end{array}$ \\
\hline I25_Relationship of data and information with strategy & 149 & 1 & 6 & 4.48 & 1.01 & 0.919 & -0.011 & -0.079 & 0.056 \\
\hline $\begin{array}{l}\text { I24_Integrity, reliability, accuracy, timeliness, safety, } \\
\text { and credibility of data and information }\end{array}$ & 149 & 1 & 7 & 4.81 & 1.12 & 0.844 & -0.068 & 0.052 & 0.035 \\
\hline $\begin{array}{l}\text { I27_Relationship of hardware and software with } \\
\text { strategy }\end{array}$ & 149 & 1 & 7 & 4.24 & 1.03 & 0.807 & 0.024 & 0.053 & 0.004 \\
\hline I26_User-friendliness of hardware and software & 149 & 1 & 6 & 4.29 & 1.00 & 0.796 & 0.077 & 0.001 & -0.092 \\
\hline I23_Availability of data and information & 149 & 1 & 6 & 4.63 & 1.11 & 0.770 & 0.038 & 0.039 & -0.018 \\
\hline I18_R\&D capabilities of employees & 149 & 1 & 6 & 4.43 & 1.13 & 0.024 & 0.815 & -0.209 & 0.126 \\
\hline $\begin{array}{l}\text { I14_Construction of manufacturing/sales } \\
\text { management process }\end{array}$ & 149 & 1 & 7 & 4.70 & 1.04 & -0.088 & 0.813 & 0.082 & -0.058 \\
\hline I19_Advanced skills of employees & 149 & 1 & 7 & 4.74 & 1.03 & -0.003 & 0.699 & 0.139 & -0.013 \\
\hline I13_Construction of R\&D management process & 149 & 1 & 7 & 4.38 & 1.22 & 0.111 & 0.628 & -0.157 & 0.120 \\
\hline I21_Skill level of employees & 149 & 1 & 7 & 5.11 & 0.93 & 0.050 & 0.513 & 0.296 & -0.150 \\
\hline I15_Construction of delivery management process & 149 & 1 & 7 & 4.44 & 1.05 & 0.044 & 0.462 & 0.039 & 0.038 \\
\hline
\end{tabular}




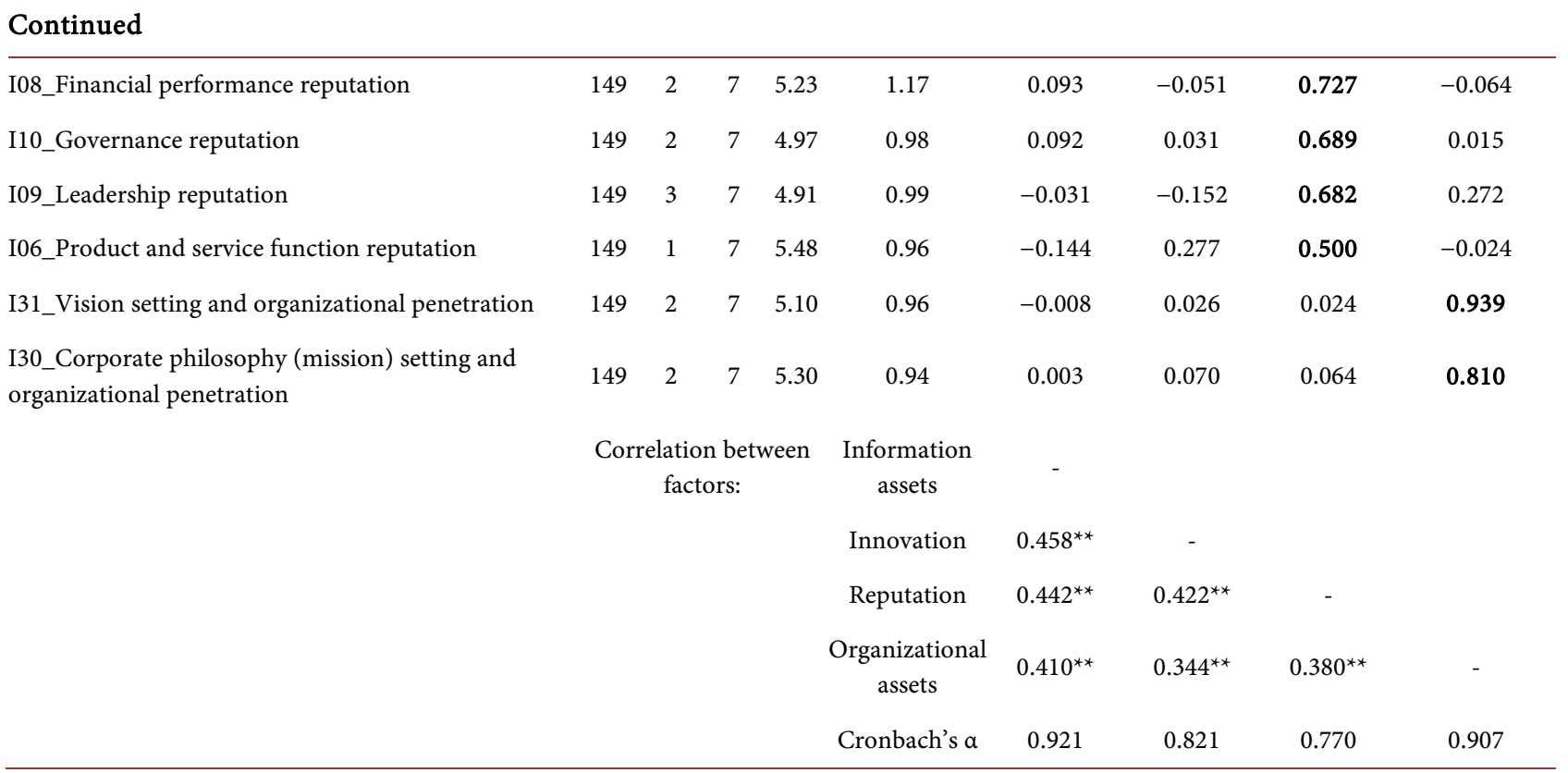

Notes: Principal factor method, factor pattern after promax rotation, factor loading $0.40, \mathrm{n}=149, \mathrm{KMO}=0.826$, Bartlett's test of sphericity $p=0.000,{ }^{* *} p<$ 0.01 (both sides). Each question item was asked with a 7-point grading scale ("1: There are issues" - "7: It is perfect").

Based on the above, it became clear that intangibles consist of information assets, innovation, corporate reputation, and organizational assets. The difference with $\mathrm{H} 2$ is that human assets and innovation have been linked up. The fact that human assets and innovation are closely related is interesting.

The next step was a confirmatory factor analysis based on $\mathrm{H} 2$, which concerns 21 items of corporate value. Table 5 shows the analysis result. The first factor, which consists of items concerning employee training and the promotion of organizational culture, was labeled "organizational value". The second factor, which consists of items related to profitability and stock value, was labeled "economic value". The third factor, which consists of items related to corporate ethics, governance, and environmental consideration, was labeled "social value". Customer value was also expected for $\mathrm{H} 2$, but no customer value-related factor was extracted because the questions about customer value were excluded from the analysis due to ceiling effects. The analysis result indicates that corporate value consists of organizational value, social value, and economic value.

\subsection{Relationship between Intangibles}

Using the verified four factors of intangibles, the causal relationship between intangibles (H3) was next verified. The analysis result is indicated in Figure 3, with a $p$-value of 0.000 . The model's goodness of fit index (GFI) was 0.806 , the CFI was 0.853 , and the RMSEA was 0.111 . Although the CFI was lower than 0.9 and the RMSEA was higher than 0.1 , it can be considered acceptable goodness of fit. The results also show that organizational assets have an impact of 0.464 on information assets, information assets have an impact of 0.530 on innovation, and innovation has an impact of 0.534 on corporate reputation. 
Table 5. Factor analysis of corporate value.

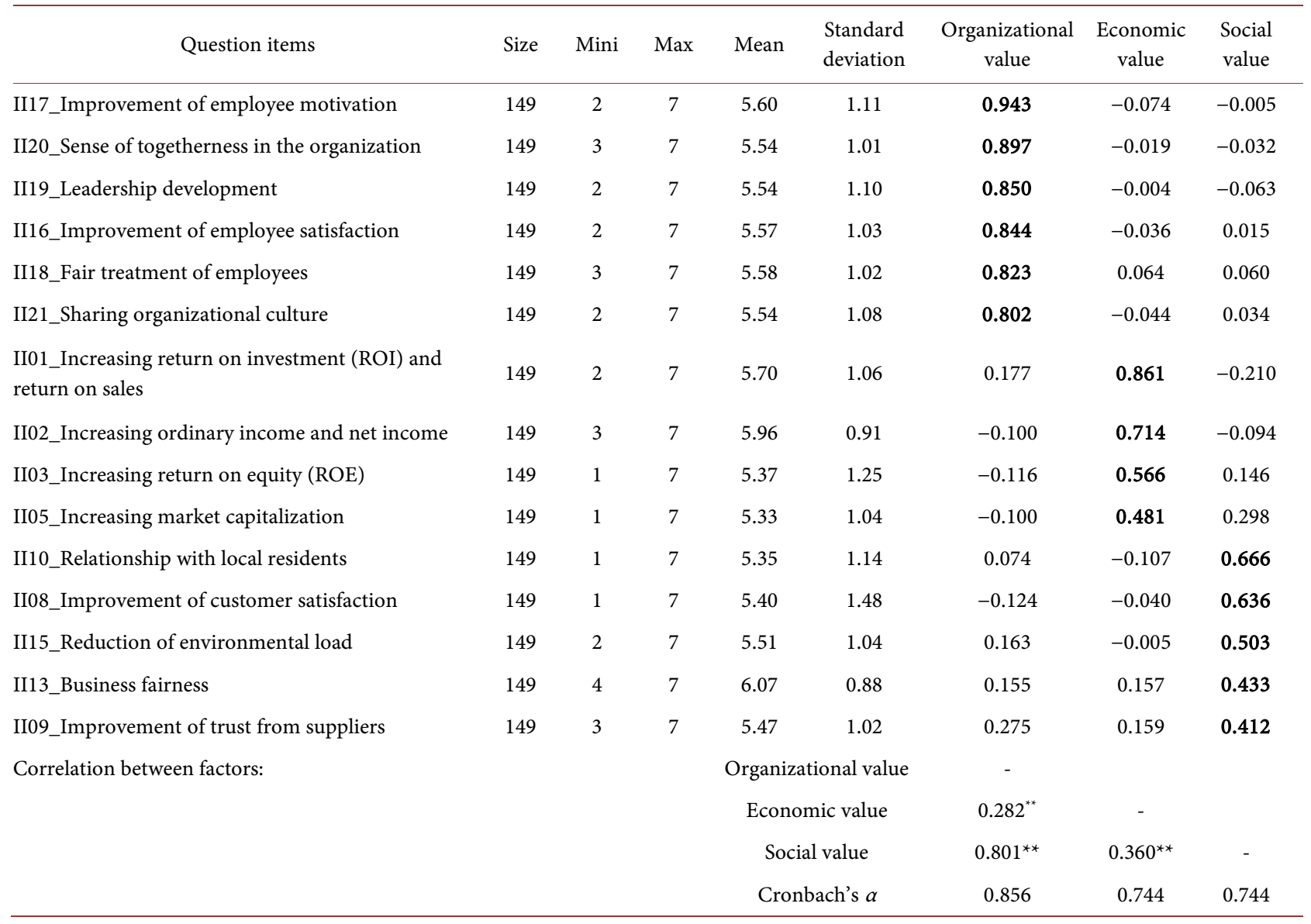

Notes: Principal factor method, factor pattern after promax rotation, factor loading 0.40, $\mathrm{n}=149$; KMO $=0.860$, Bartlett's test of sphericity $p=0.000$; ${ }^{* *} p<$ 0.01 (both sides). Each question item was asked with a 7-point grading scale ("1: Completely ignored" - "7: Total emphasis").

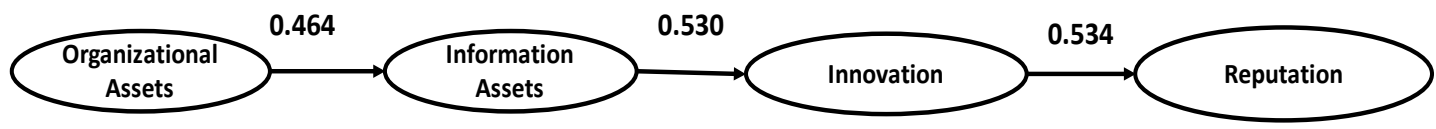

Figure 3. Causal model between intangibles.

\subsection{Relationship between Intangibles and Corporate Value}

The next step was to verify the causal relationship between intangibles and corporate value ( $\mathrm{H} 4)$ and the impact of strategies and management control systems (H5), using a covariance structure analysis. To analyze H4, we used a sample of 149 companies; in the case of $\mathrm{H} 5$, a sample of 131 companies was divided into 54 prospector companies that emphasized interactive control, 48 defender companies that emphasized diagnostic control ${ }^{2}$, and 29 ambidextrous companies that have both prospector and defender attributes.

First, we verify H4, which had a sample size of 149 companies. The analysis results indicate $\chi^{2}$ of 66.28 , a degree of freedom of 14 , and a $p$-value of 0.000 .

${ }^{2}$ The companies were classified between those with six or more points in questions about prospective strategy and interactive control and those with six or more points in questions about defensive strategy and diagnostic control. 
Figure 4 illustrates these results, which confirms the initial hypothesis that intangibles affect corporate value. The model's GFI was 0.889 , and CFI was 0.873 , which can be considered a high degree of goodness of fit. The RMSEA was below 0.1 , at 0.059 . The standardization estimate was 0.397 . These results demonstrate that intangibles influence corporate value, which supports $\mathrm{H} 4$.

Next, we analyze the impact of intangibles of prospector companies of $\mathrm{H} 5$ on corporate value. The analysis results in Figure 5 indicate that the model of prospector companies, which excluded reputation from intangibles, had the highest goodness of fit. $\chi^{2}$ was 47.808 , the degree of freedom was 9 , and the $p$-value was 0.000. The model's GFI was 0.899 , the CFI was 0.878 , and RMSEA was less than 0.1 , at 0.92 . The standardization estimate was 0.389 .

In the same manner, we analyze the impact of intangibles of defender companies on corporate value, as stated in H5. The analysis results in Figure 6 indicate that the model of defender companies, which excluded innovation from intangibles, had the highest goodness of fit. $\chi^{2}$ was 44.959 , the degree of freedom was 9 , and the $p$-value was 0.000 . The model's GFI was 0.903 , CFI was 0.894 , and RMSEA was less than 0.1 , at 0.012. The standardization estimate was 0.403 .

These results indicate that the intangibles that affect corporate value in prospector companies, which emphasize interactive control, are different from those in defender companies that emphasize diagnostic control.

The last analysis is of the impact of ambidextrous management of $\mathrm{H} 5$, which has both prospector and defender attributes, on intangibles and corporate value. $\chi^{2}$ was 38.129 , the degree of freedom was 14 , and the $p$-value was 0.000 . The model's GFI was 0.806 , CFI was 0.812, and RMSEA was 0.168 . The standardization estimate was 0.687 . Because the model's goodness of fit is poor, it was not possible to demonstrate a solid result for ambidextrous companies. Table 6 shows the structural equation modeling (SEM) results from $\mathrm{H} 3$ to $\mathrm{H} 5$.

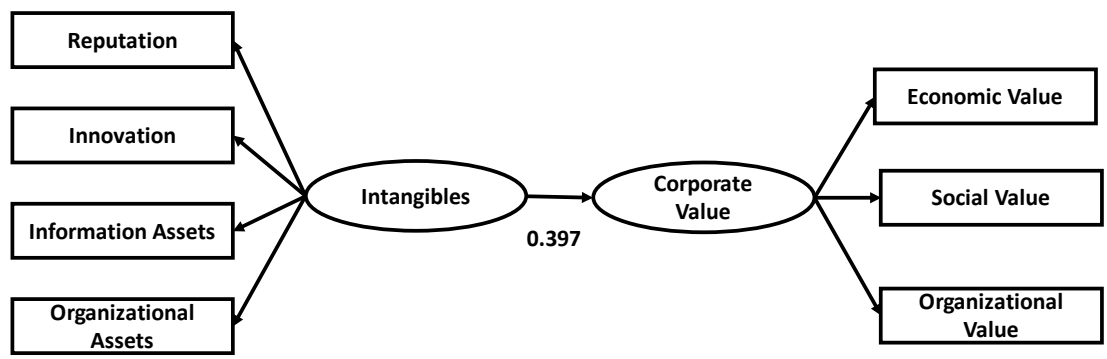

Figure 4. The causal model of intangibles and corporate value (overall).

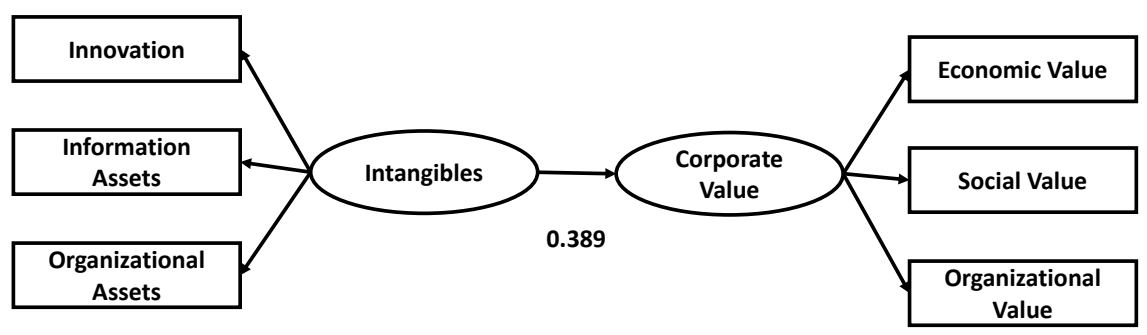

Figure 5. The causal model of intangibles and corporate value (prospector companies). 


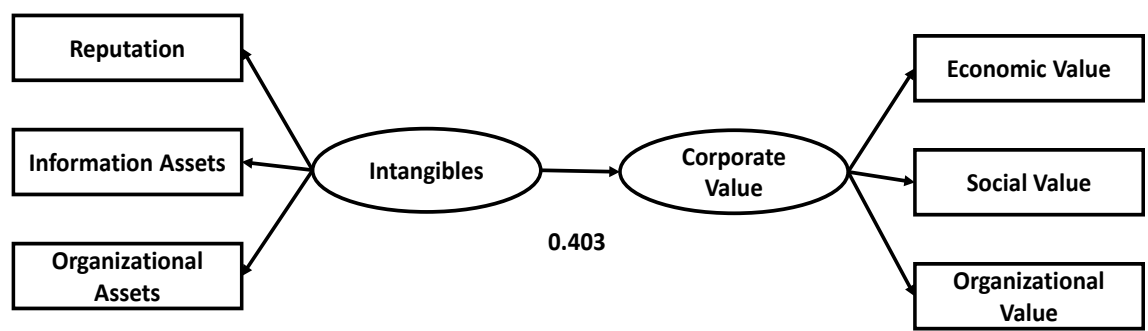

Figure 6. The causal model of intangibles and corporate value (defender companies).

Table 6. The results of $\mathrm{H} 3$ to $\mathrm{H} 5$.

\begin{tabular}{|c|c|c|c|c|c|c|c|}
\hline & Hypothesis & $x^{2}$ & $d f$ & $p$ value & GFI & CFI & RMSEA \\
\hline $\mathrm{H} 3$ & The causal model between intangibles & 328.597 & 116 & 0.000 & 0.806 & 0.853 & 0.111 \\
\hline $\mathrm{H} 4$ & $\begin{array}{l}\text { The causal model of intangibles and } \\
\text { corporate value (overall) }\end{array}$ & 66.280 & 14 & 0.000 & 0.889 & 0.873 & 0.059 \\
\hline H5-1 & $\begin{array}{l}\text { The causal model of intangibles and } \\
\text { corporate value (prospector companies) }\end{array}$ & 47.808 & 9 & 0.000 & 0.899 & 0.878 & 0.092 \\
\hline H5-2 & $\begin{array}{l}\text { The causal model of intangibles and } \\
\text { corporate value (defender companies) }\end{array}$ & 44.959 & 9 & 0.000 & 0.903 & 0.894 & 0.101 \\
\hline H5-3 & $\begin{array}{l}\text { The causal model of intangibles and } \\
\text { corporate value (ambidexterity companies) }\end{array}$ & 38.129 & 14 & 0.000 & 0.806 & 0.812 & 0.168 \\
\hline
\end{tabular}

\section{Conclusion}

In this study, we verified a set of hypotheses about the relationship between intangibles and corporate value, as well as the impact of strategies and management control systems on that relationship. Three discoveries were made with this verification.

The first discovery is that intangibles consist of corporate reputation, innovation, information assets, and organizational assets. The hypothesis assumed that human assets were part of intangibles, but the results showed that they are connected to innovation. As far as innovation is concerned, the skills and creativity of employees play a major role.

The second aspect is that corporate value consists of economic value, social value, and organizational value. This result agrees with the view of Freeman, Harrison, \& Wicks (2007), who stated that all stakeholders are in an equal relationship, as well as with the results obtained by Aoki, Iwata, \& Sakurai (2009) and Ito \& Sekiya (2016), who performed similar verifications. Therefore, it can be said that companies take various stakeholders into consideration when creating value. The third discovery is that if strategies and management control systems vary, so do the intangibles that affect corporate value. The results indicate that in prospector companies, reputation does not influence corporate value. This is attributed to the fact that instead of reducing reputation risk, these companies seek to create new markets through innovation. By contrast, it is clear that innovation does not impact corporate value in defender companies. It is believed that defender companies emphasize their reputation to retain existing markets and customers. 
The limit of this paper is that companies that have both sides of prospector companies and defender companies do not specify ambidextrous companies based on hypothesis 5. Therefore, the model's goodness of fit was poor. Originally, the characteristics of a company that grasped ambidextrous management should have been established as some questionnaire items.

\section{Acknowledgements}

This work was supported by JSPS KAKENHI Grant Numbers JP18K01940 (Ito) and JP16K17210 (Sekiya). Ito set a hypothetical model, Umeda arranged the previous studies and conducted statistical analysis, and Sekiya verified this empirical study.

\section{Conflicts of Interest}

The authors declare no conflicts of interest regarding the publication of this paper.

\section{References}

Andrews, K. R. (1987). The Concept of Corporate Strategy (3rd ed.). Homewood, IL: R.D. Irwin.

Ansoff, H. I. (1965). Corporate Strategy: An Analytic Approach to Business Policy for Growth and Expansion. New York: McGraw-Hill.

Aoki, A., Iwata, H., \& Sakurai, M. (2009). Management Perception on Reputation Management: Analysis of Enquete Research from the Viewpoint of Management Accounting. Kaikeigaku-Kenkyu, 35, 33-70.

Becker, G. S. (1964). Human Capital: A Theoretical and Empirical Analysis, with Special Reference to Education. New York: National Bureau of Economic Research.

Blair, M. M., \& Wallman, S. M. H. (2001). Unseen Wealth: Report of the Brookings Task Force on Intangibles. Washington DC: Brookings Institution Press.

Burgelman, R. A. (2002). Strategy Is Destiny: How Strategy-Making Shapes a Company's Future. New York: Free Press.

Carmeli, A. (2004). The Link between Organizational Elements, Perceived External Prestige and Performance. Corporate Reputation Review, 6, 314-331. https://doi.org/10.1057/palgrave.crr.1540002

Carmeli, A., \& Tishler, A. (2005). Perceived Organizational Reputation and Organizational Performance: An Empirical Investigation of Industrial Enterprises. Corporate Reputation Review, 8, 13-30. https://doi.org/10.1057/palgrave.crr.1540236

Chenhall, R. H. (2005). Integrative Strategic Performance Measurement Systems, Strategic Alignment of Manufacturing, Learning and Strategic Outcomes: An Exploratory Study. Accounting, Organizations and Society, 30, 395-422. https://doi.org/10.1016/j.aos.2004.08.001

Chien, S.-H., \& Chao, M.-C. (2011). Intellectual Capital and New Product Sale Performance of the Financial Services Industry in Taiwan. Service Industries Journal, 31, 2641-2659. https://doi.org/10.1080/02642069.2010.506572

Donate, M. J., Peña, I., \& Sánchez de Pablo, J. D. (2016). HRM Practices for Human and Social Capital Development: Effects on Innovation Capabilities. The International Journal of Human Resource Management, 27, 928-953.

https://doi.org/10.1080/09585192.2015.1047393 
Drucker, P. F. (1954). The Practice of Management. New York: Harper \& Row.

Edvinson, L., \& Malone, M. S. (1997). Intellectual Capital: Realizing Your Company’s True Value by Finding Its Hidden Brainpower. New York: Harper Business.

Fombrun, C. J., \& Shanley, M. (1990). What's in a Name? Reputation Building and Corporate Strategy. Academy of Management Journal, 33, 233-258. https://doi.org/10.5465/256324

França, A., \& Rua, O. L. (2018). Relationship between Intangible Resources, Absorptive Capacities and Export Performance. Tourism \& Management Studies, 14, 94-107. https://doi.org/10.18089/tms.2018.14108

Freeman, R. E., Harrison, J. S., \& Wicks, A. C. (2007). Managing for Stakeholders: Survival, Reputation, and Success. New Haven, CT: Yale University Press.

Hosomi, S. (2009). Soshiki-Shihon to Kigyou Gyoseki tono Kankei: Jyoujyo Kigyou Kanrisyoku ni taisuru Shitsumonhyou Cyousa niyoru Chiteki-Shihon no Jisyouteki Kenkyu. Kaikei, 176, 108-122.

Hosomi, S. (2011). Chiteki-Shihon to Kigyou Gyoseki tono Kankei: Jyoujyo Kigyou Kanrisyoku ni taisuru Shitsumonhyou Cyousa niyoru Chiteki-Shihon no Jisyouteki Kenkyu. Kaikei, 180, 44-59.

Hosomi, S. (2014). Study on the Relation between Intellectual Capital and Corporate Performance for the Management of Organisational Capital. SKOPE Research, 120, 1-47.

Itami, H. (1987). Jinponshugi: Kawaru Keiei Kawaranu Genri. Tokyo: Chikuma-syobo.

Ito, K. (2007). Soshiki wo Ikasu Kanrikaikei: Sosikimodel to Gyoseki-Kanrikaikei tono Kankeisei. Tokyo: Seisansei-Syuppan.

Ito, K., \& Sekiya, H. (2016). Developing the Theoretical Model between Intangibles and Corporate Values. Kaikeigaku-Kenkyu, 42, 1-32.

Ito, K., Ito, K., Shinmura, H., \& Sakurai, M. (2011). Analysis of Research Result on Reputation Management Based on Empirical Studies. Senshu Syogaku-Ronsyu, 93, 15-40.

Iwata, H. (2012). The Relationship between Corporate Reputation and Financial Performance: The Japanese Perspective. Senshu Management Journal, 2, 13-22.

Kaplan, R. S., \& Norton, D. P. (2004). Strategy Maps: Converting Intangible Assets into Tangible Outcomes. Boston, MA: Harvard Business School Press.

Kowalczyk, S. J., \& Pawlish, M. J. (2002). Corporate Branding through External Perception of Organizational Culture. Corporate Reputation Review, 5, 159-174. https://doi.org/10.1057/palgrave.crr.1540172

Kozakai, M. (2008). BSC ni yoru Senryaku Sikou no IT Manejimento. Tokyo: Hakuto Syobo.

Lev, B. (2001). Intangibles: Management, Measurement, and Reporting. Washington DC: Brookings Institution Press.

McKinsey Company Inc. (2010). Valuation: Measuring and Managing the Value of Companies (3rd ed.). New York: Wiley.

Miles, R. E., \& Snow, C. C. (1978). Organizational Strategy, Structure and Process. New York: McGraw-Hill.

Mintzberg, H., Ahlstrand, B., \& Lampel, J. (1998). Strategy Safari: A Guided Tour through the Wilds of Strategic Management. New York: Free Press.

Mithas, S., Ramasubbu, N., \& Sambamurthy, V. (2011). How Information Management Capability Influences Firm Performance. MIS Quarterly, 35, 237-256.

https://doi.org/10.2307/23043496 
Nihon Kanrikaikei Gakkai Study Group (2015). Kigyou Kachi Souzo ni Mukete no Intanjiburuzu no Fukugouteki Katsuyou. Nihon Kanrikakei Gakkai 2013 Study Group Kenkyu-Houkokusho, JAMA.

Nishii, T. (2012). A Note on the Concept of Interactive Control. Senshu Syogaku-Ronsyu, 94, 171-193.

Nishimura, Y. (2001). Kenkyu Kaihatsu Senryaku no Kaikei Jyouhou. Tokyo: Hakuto Syobo.

Nonaka, I., \& Takeuchi, H. (1996). Chishiki Souzou Kigyou. Tokyo: Toyo-Keizai Shinpousha.

O’Reilly, C. A., \& Tushman, M. L. (2004). The Ambidextrous Organization. Harvard Business Review, 82, 74-82.

Odagiri, H. (2010). Kigyou Keizai-Gaku Dai-2-Han. Tokyo: Toyo-Keizai Shinpousha.

Peters, T. J., \& Waterman, R. H. (1982). In Search of Excellence: Lessons from America's Best-Run Companies. New York: Harper \& Row.

Ponzi, L., Fombrun, C., \& Gardberg, N. A. (2011). RepTrak ${ }^{\mathrm{Tm}}$ Pulse: Conceptualizing and Validating a Short-Form Measure of Corporate Reputation. Corporate Reputation Review, 14, 15-35. https://doi.org/10.1057/crr.2011.5

Porter, M. E. (1980). Competitive Strategy: Techniques for Analyzing Industries and Competitors. New York: Free Press.

Porter, M., \& Kramer, M. R. (2011). The Big Idea: Creating Shared Value. How to Reinvent Capitalism: And Unleash a Wave of Innovation and Growth. Harvard Business Review, 89, 62-77.

Riahi-Belkaoui, A., \& Pavlik, E. (1991). Asset Management Performance and Reputation Building for Large US Firms. British Journal of Management, 2, 231-238.

https://doi.org/10.1111/j.1467-8551.1991.tb00029.x

Roberts, P. W., \& Dowling, G. R. (1997). How Do Reputations Affect Corporate Performance? The Value of a Firm's Corporate Reputation: How Reputation Helps Attain and Sustain Superior Profitability. Corporate Reputation Review, 1, 72-76. https://doi.org/10.1057/palgrave.crr.1540020

Roberts, P. W., \& Dowling, G. R. (2002). Corporate Reputation and Sustained Superior Financial Performance. Strategic Management Journal, 23, 1077-1093.

https://doi.org/10.1002/smj.274

Sakurai, M. (1987). Software Genkakeisan: Genkakanri, Kakakukettei, Shisanhyouka notameni. Tokyo: Hakuto Syobo.

Sakurai, M. (2015). Kanrikaikei Dai 6 Pan. Tokyo: Doubunkan-Syuppan.

Shubita, M. F. (2019). Intellectual Capital and Market Value: Evidence from Jordan. Investment Management and Financial Innovations, 16, 37-45. https://doi.org/10.21511/imfi.16(4).2019.04

Simons, R. (1987). Accounting Control Systems and Business Strategy: An Empirical Analysis. Accounting, Organizations and Society, 12, 375-385.

https://doi.org/10.1016/0361-3682(87)90024-9

Simons, R. (1990). The Role of Management Control Systems in Creating Competitive Advantage: New Perspectives. Accounting, Organizations and Society, 15, 127-143. https://doi.org/10.1016/0361-3682(90)90018-P

Subramanian, A., \& Nilakanta, S. (1996). Organizational Innovativeness: Exploring the Relationship between Organizational Determinants of Innovation, Types of Innovations, and Measures of Organizational Performance. Omega, 24, 631-647.

https://doi.org/10.1016/S0305-0483(96)00031-X 
Tseng, C.-Y., \& Goo, Y.-J. (2005). Intellectual Capital and Corporate Value in an Emerging Economy: Empirical Study of Taiwanese Manufacturers. R\&D Management, 35, 187-201. https://doi.org/10.1111/j.1467-9310.2005.00382.x

Ubaldo, M. D., \& Siedschlag, I. (2020). Investment in Knowledge-Based Capital and Productivity: Firm-Level Evidence from a Small Open Economy. The Review of Income and Wealth, 63, S49-S67.

Uchiyama, A. (2010). The Management of Human Resources as Intangibles, and Management Accounting: for Integrated Performance Management Systems. Chiba Daigaku Keizai-Kenkkyu, 24, 1-25.

Umeda, H. (2018). Kigyoukachi Souzou notameno Intanjibuluzu Manejimento. Senshu Daigaku Syuppankai.

Yee, R. W. Y., Yeung, A. C. L., \& Cheng, T. C. E. (2010). An Empirical Study of Employee Loyalty, Service Quality and Firm Performance in the Service Industry. International Journal Production Economics, 124, 109-120. https://doi.org/10.1016/j.ijpe.2009.10.015

Youndt, M. A., Subramaniam, M., \& Snell, S. A. (2004). Intellectual Capital Profiles: An Examination of Investments and Returns. Journal of Management Studies, 41, 335-361. https://doi.org/10.1111/j.1467-6486.2004.00435.x 